\title{
Integrated Use of Nanomechanical, Histological, and Biochemical Biomarkers of Oreochromis niloticus as Signs of Metal Stress
}

\author{
Hamada S. Salem * , Ahmed E. Hagras, Heba Allah M. El-Baghdady, Ahmed M. El-Naggar \\ Zoology Department, Faculty of Sciences, Mansoura University, Mansoura, Egypt
}

\begin{abstract}
The bioaccumulation of heavy metals in fish is a recognized environmental problem. Heavy metals, after leaking into the water, penetrate fish directly through the gill and later the skin. Fish develops protective defense mechanisms against the damaging effects of heavy metals. The present investigation aimed to determine the magnitude of five heavy metals (cadmium, iron, manganese, cobalt, and lead) in the muscle tissues of the Nile tilapia (Oreochromis niloticus) and their possible impacts on its histological, nanomechanical, and biochemical biomarkers. The results showed that fish muscle from the polluted site accumulated high levels of the tested heavy metals compared to the reference site. Biochemical profile of the Nile tilapia showed elevated serum glucose, total proteins, uric acid, creatinine, bilirubin, superoxide dismutase, and malondialdehyde in exposed fish compared to their conspecifics at reference site. Histological examination of the liver showed severe alterations in the hepatic tissues. Nanomechanical properties, signified by roughness and stiffness, confirmed the damaging effect of metals on hepatocytes. These findings provide a rational application of histological, nanomechanical and biochemical parameters to be used as indicators of metal stress in aquatic organisms. Therefore, it can be suggested that integrated biomarker response is a comprehensive index of all biomarkers and a good indicator of the health status of aquatic ecosystem and have proven to be very useful in the environmental pollution monitoring.
\end{abstract}

Keywords: Antioxidants, Heavy metals, Integrated Biomarker Response, Nanomechanical, Oxidative Stress.

\section{INTRODUCTION}

Drainage canals in Egypt receive tremendous amounts of wastewater from various pollution sources. These drains discharge into the Nile River, lakes, and seas. Ultimately, various pollutants find their way to drinking water (Authman et al., 2013; Khalil et al., 2017). Water pollutants lead to physicochemical and biological changes in the aquatic ecosystems which may induce ecological disruption (Soundararajan and Veeraiyan, 2014; Oyeleke et al., 2018) and the destruction of the aquatic flora and fauna. Unfortunately, a large portion of the population in the Nile Delta obtains fish from these polluted streams and drains, leading to many health concerns for humans.

Many pollutants exhibit biomagnification and bioaccumulation abilities with varied adverse impacts on aquatic organisms and humans (Van der Oost et al., 2003; Kumar Maurya et al., 2019). Heavy metals represent a major class of these contaminants because of their high toxicity and long persistence in aquatic food chains and food webs. They are introduced to aquatic ecosystems through waste discharged from various industries such as the sugarbeet industry (Yap et al., 2015; Qadri and Bhat, 2020). These elements are also known as trace elements because they exist in minor concentrations in the biological systems of living organisms (Förstner and Wittmann, 2012; Nofal et al., 2019). Depending on their concentration in water, they may cause useful or damaging effects on living organisms (Förstner and Wittmann, 2012; Museum, 2015). Some heavy metals, such as iron (Fe), copper $(\mathrm{Cu})$, nickel $(\mathrm{Ni})$, manganese $(\mathrm{Mn})$, and Zinc $(\mathrm{Zn})$, are biologically essential and become toxic at relatively high concentrations. Others, such as arsenic (As), chromium $(\mathrm{Cr})$, cadmium $(\mathrm{Cd})$, lead $(\mathrm{Pb})$, and mercury $(\mathrm{Hg})$, have no known essential function in living organisms and are toxic even at low concentrations (Förstner and Wittmann, 2012).

Fish represent a highly nutritive and inexpensive source of animal protein in Egypt. Fish muscles are rich in vitamins, essential minerals, and unsaturated fatty acids (Medeiros et al., 2012). Being at high rank in the aquatic food chain, fish metabolizes, concentrates, and accumulates pollutants from water (den Besten and Munawar, 2016). These pollutants can disrupt metabolic pathways at the cellular level, eliciting variable cellular responses depending on the magnitude and property of each metal (Monteiro et al., 2010). Pollutants bring about oxidative stress by catalysing the production of reactive oxygen species (ROSs) such as hydrogen peroxide $\left(\mathrm{H}_{2} \mathrm{O}_{2}\right)$, which may cause DNA mutations as well as lipid peroxidation (Jaishankar et al., 2014). Fish develops protective defence mechanisms against the damaging effects of heavy metals and other pollutants (Filipović and Raspor, 2003). However, heavy metals at excess levels can damage vital organs, disrupt immune response, alter hematological parameters, and diminish fish adaptation and resistance to diseases (Sinha et al., 2002; Förstner and Wittmann, 2012). Heavy metal toxicity can also disrupt the normal hormonal balance, impair hormone production, and decrease reproduction ability of fish (Jaishankar et al., 2014).

The assessment of biological effects of pollutants allows for monitoring water pollution with fast 
responses (Gharred and Naija, 2015). Therefore, fish could be used as a "warning system" to indicate the presence of pollutants in natural aquatic (El-Hais et al., 2017). Biochemical alternations have been also proved sensitive biomarkers for the detection of interactions between pollutants and biological compounds (Gabr, et al., 2020; El-Hais et al., 2017). This study, therefore, investigated the utilization of an integrated biomarker approach of histological, nanomechanical, biochemical, and oxidative stress biomarkers in Oreochromis niloticus (Linnaeus, 1758) as a biological indicator of the health status of the freshwater ecosystem.

\section{MATERIALS AND METHODS}

\section{Study Area}

This study was conducted over 12 months from December 2017 to November 2018. The upstream locality of the Kalabsho drainage canal, located at $31^{\circ} 25^{\prime} 57.0^{\prime \prime} \mathrm{N} 31^{\circ} 24^{\prime} 09.5^{\prime \prime} \mathrm{E}$, was selected as a polluted site. The canal directly receives industrial effluents from a sugar beet factory, Abou Sherif, Belkas, Dakahlia Governorate. The Damietta branch of the Nile River at Meet Badr Khamees village $\left(31^{\circ} 02^{\prime} 05.4^{\prime \prime} \mathrm{N}\right.$ $\left.31^{\circ} 20^{\prime} 00.5^{\prime \prime} \mathrm{E}\right)$ also was selected as a reference site.

\section{Heavy Metal Analysis}

Fish samples were collected two times per season by fishing nets from the studied habitats. Fish were transferred alive to the laboratory in a water container with sufficient oxygenation. Muscle samples were obtained and kept in nylon bags at a temperature of $-20^{\circ} \mathrm{C}$ until conducting heavy metal analysis. After thawing at room temperature, the muscle samples were kept at $70^{\circ} \mathrm{C}$ in a digital microwave for one hour. Each sample was ground in a mortar to obtain fine smooth particles. A volume of $20 \mathrm{ml}$ concentrated $\mathrm{HNO}_{3}$ (PioChem, Egypt) was added to $1 \mathrm{~g}$ of each ground sample for digestion. After then $10 \mathrm{ml}$ of concentrated $\mathrm{HNO}_{3}$ and $\mathrm{HClO}_{4}$ (4:1; PioChem, Egypt) were added, followed by heating the samples at $120^{\circ} \mathrm{C}$ until the sample becomes completely dry. The dried samples were diluted to 50 $\mathrm{ml}$ with water and concentrated $\mathrm{HNO}_{3}$ (4:1) and filtered using filter paper (Dhaneesh et al., 2012).

Atomic absorption spectrophotometer (Buck Scientific Accusys 211, series) was used to estimate the concentrations of $\mathrm{Cd}, \mathrm{Fe}, \mathrm{Mn}, \mathrm{Co}$, and $\mathrm{Pb}$ (American Public Health Association, 2012). All samples were done in triplicate. All chemicals were of analytical grade. Glassware was kept in $10 \%$ nitric acid and then washed with ultrapure water. Quality assurance and control were achieved using blanks and standards to ensure high precision and accuracy.

\section{Biochemical analyses}

Blood was withdrawn from the caudal vein using a sterilized long needle. About $1 \mathrm{ml}$ of blood from male fish was withdrawn and preserved in Eppendorf tubes for serum analyses. The blood was left to coagulate, and then centrifuged at $3000 \mathrm{rpm}$ for 10 minutes. The serum was then isolated in another tube to determine the levels of enzymes. Standard kits (Bio-diagnostic, Egypt) were used for the determination of glucose
(Trinder, 1969), total protein (Henry, 1964), bilirubin (Lott and Doumas, 1993), uric acid (Barham and Trinder, 1972), and creatinine (Henry et al., 1974). Colorimetric techniques were conducted using an Ultraspec III spectrophotometer (Pharmacia LKB Biochrom Ltd, UK) at the appropriate wavelengths.

The concentration of antioxidant enzyme superoxide dismutase (SOD) (Unit/ml) was measured indirectly by inhibiting the Cytochrome c reduction (McCord and Fridovich, 1969). Malondialdehyde (MDA) content was measured as an indicator of lipid peroxidation. MDA concentration ( $\mathrm{nmol} / \mathrm{ml}$ ) was measured based on the thiobarbituric acid method (Jain et al., 1989) using diagnostic kits provided by Bio-diagnostic (Egypt). Reduced glutathione (GSH) was estimated calorimetrically according to Beutler et al. (1963) using kits provided by Bio-diagnostic (Egypt).

\section{Histopathological Examination}

Tilapia was dissected carefully to obtain muscles. Muscle tissue was isolated and placed in $10 \%$ neutral formaldehyde. The preserved samples were processed according to Bernet et al., (1999) protocol. Processed specimens were embedded in paraffin wax. Embedded samples were cut into $5 \mu \mathrm{m}$-thick ribbons using a microtome. Ribbons were mounted on clean slides. Finally, tissue preparations were stained with Hematoxylin and Eosin. Histological examination of tissue was performed using a high-power Olympus light microscope with software (Scope Tek DCM510).

\section{Atomic Force Microscopy}

Paraffin-embedded liver tissue was dewaxed, rehydrated, and sectioned. Atomic force microscopy (AFM) was used for topography with error signal mode (ESM) to determine the configuration and height of the liver parenchyma. Stiffness and roughness of the liver tissue were examined (Melling et al., 2004). The measurements were conducted using FlexAFM3. All images were obtained in contact mode by using a nanoconductive silicon probe and Nanosurf C3000 (Version 3.5.0.31) software. The scan area was $10 \times 10 \mu \mathrm{m}^{3}$ and the number of data points was $256 \times 256$ at a scan rate of $1 \mathrm{HZ}$. Scans were performed in the air.

\section{Data Processing and Statistical analysis}

An integrated biomarker response (IBR) developed by Beliaeff and Burgeot (2010), to provide an integrated comprehensive index, was applied. This index combines all biomarkers together to offer an effective method to evaluate the adaptive response of a living organism under stress. IBR was calculated as follows:

$$
\mathrm{X}^{\prime}=(\mathrm{u}-\mathrm{m}) / \mathrm{s}
$$

Where $X^{\prime}$ is a standardized value of a parameter, $u$ is the value of the parameter, $\mathrm{m}$ is the overall mean value of the parameter, $s$ is the standard deviation of the parameter data.

$$
\begin{aligned}
& Y=X^{\prime} \quad \text { (in case of activation) } \\
& Y=-X^{\prime} \quad \text { (in case of inhibition) } \\
& Z=Y+\mid \text { Min } \mid
\end{aligned}
$$

Where $\mathrm{Z}$ is the score of the parameter; $|\mathrm{Min}|$ is the minimum value of all data of the parameter. 
To estimate the overall metal load in the muscle tissue, the metal pollution index (MPI) was determined according to Javed et al. (2016) as follows:

$$
\mathrm{MPI}=\left(\mathrm{CM}_{1} \times \mathrm{CM}_{2} \times \mathrm{CM}_{3} \times \mathrm{CM}_{4} \ldots \mathrm{CM}_{\mathrm{n}}\right)^{1 / \mathrm{n}}
$$

Where CMn is the concentration of each metal (n) in the muscle samples.

All data were represented as Mean \pm SD. Pearson correlation was utilized to determine the usefulness of IBR and MPI. Differences in heavy metals concentrations, biochemical measures, and nanomechanical properties were statistically tested using $\mathrm{t}$ test on SPSS Software (version 20). Differences were considered significant at a probability of $\leq 0.05$ and non-significant at a probability of $>0.05$.

\section{RESULTS}

\section{Heavy Metals}

The accumulation trend of the heavy metals in muscle of $O$. niloticus was $\mathrm{Fe}>\mathrm{Mn}>\mathrm{Cd}>\mathrm{Pb}>\mathrm{Co}$ in the polluted and the reference site. The mean concentrations of heavy metals in muscle samples of tilapia from the polluted site were significantly $(p \leq 0.05)$ higher compared to those from the reference site (Table 1$)$. MPI showed a significant $(p \leq 0.05)$ high mean value in the exposed fish population compared to the reference population.

Table 1. Measured heavy metal concentrations, $\mathrm{Cd}, \mathrm{Fe}$, $\mathrm{Mn}, \mathrm{Co}$, and $\mathrm{Pb}$, in the muscle fish samples collected from the polluted site and reference site.

\begin{tabular}{lll}
\hline $\begin{array}{c}\text { Parameter } \\
\text { (ppm) }\end{array}$ & Polluted Site & Reference Site \\
\hline Cd & $0.987 \pm 0.216^{*}$ & $0.376 \pm 0.145$ \\
Fe & $3.838 \pm 0.888^{*}$ & $1.209 \pm 0.740$ \\
Mn & $1.787 \pm 0.643^{*}$ & $0.862 \pm 0.402$ \\
Co & $0.797 \pm 0.121^{*}$ & $0.356 \pm 0.076$ \\
Pb & $0.832 \pm 0.208^{*}$ & $0.359 \pm 0.126$ \\
MPI & $1.34 \pm 0.13^{*}$ & $0.53 \pm 0.05$ \\
\hline
\end{tabular}

Data are in mean $\pm \mathrm{SD} ;{ }^{*}$ indicates a significant difference at a $5 \%$ probability level.

Fish serum biochemistry and antioxidant Biomarkers

Table 2 shows a significant elevation $(p \leq 0.05)$ in mean concentrations of serum glucose, total proteins, uric acid, creatinine, bilirubin, SOD, and MDA in tilapia from the polluted site during the study period as compared to the reference site. A significant decline was detected in GSH mean concentration in tilapia sampled from the polluted site as compared to those from the reference site. The IBR of the exposed tilapia significantly exceeded that of the reference population (Figure 1). Further, IBR exhibited a significant $(p \leq 0.05)$ correlation with MPI $(\mathrm{r}=0.7134)$.

\section{Histopathological Examination}

Liver samples from fish inhabiting the reference site showed intact hepatocytes, central veins, and normal pancreatic tissue. Few areas of degeneration were observed (Figure 2). At the polluted site, liver samples had severe vacuolar degeneration, severe congestion in the hepatic blood vessels, and parasitic encapsulation (Figure 2). There were also diffuse swelling, necrotic changes, and infiltration of mononuclear cells in between the hepatocytes (Figure 3). Necrotic changes in the hepatocytes were also relevant (Figure 3).

\section{Atomic Force Microscopy}

In the present study, AFM was utilized for cell imaging and observing changes in surface roughness and stiffness of hepatocytes from tilapia (Figure 4 and 5). The liver of the fish inhabiting the polluted site showed increased roughness and stiffness. The topography of liver parenchyma from fish inhabiting the reference site appeared relatively normal with decreased roughness and stiffness. The mean values of roughness and stiffness of liver samples from tilapia inhabiting the drainage canal were significantly $(p \leq 0.05)$ higher than those collected from the Nile river.

Table 1. Fish serum biochemistry and antioxidant biomarkers of fish samples collected from the polluted site in comparison with reference site.

\begin{tabular}{lll}
\hline $\begin{array}{l}\text { Measured } \\
\text { parameter }\end{array}$ & Polluted Site & $\begin{array}{l}\text { Reference } \\
\text { Site }\end{array}$ \\
\hline Glucose $(\mathrm{mg} / \mathrm{dl})$ & $210.0 \pm 98.1^{*}$ & $92.6 \pm 39.9$ \\
Total Protein $(\mathrm{g} / \mathrm{dl})$ & $3.82 \pm 2.69^{*}$ & $2.56 \pm 1.02$ \\
Uric Acid $(\mathrm{mg} / \mathrm{dl})$ & $10.10 \pm 6.74^{*}$ & $3.20 \pm 2.43$ \\
Creatinine $(\mathrm{mg} / \mathrm{dl})$ & $0.43 \pm 0.13^{*}$ & $0.20 \pm 0.16$ \\
Bilirubin $(\mathrm{mg} / \mathrm{dl})$ & $1.14 \pm 1.18^{*}$ & $0.42 \pm 0.19$ \\
SOD $(\mathrm{U} / \mathrm{ml})$ & $52.94 \pm 21.56^{*}$ & $30.96 \pm 11.07$ \\
MDA (nmol/ml) & $11.02 \pm 4.33^{*}$ & $8.71 \pm 2.24$ \\
GSH $(\mathrm{mg} / \mathrm{dl})$ & $3.77 \pm 2.45^{*}$ & $6.57 \pm 1.20$ \\
IBR & $8.72 \pm 5.25^{*}$ & $1.46 \pm 0.84$ \\
\hline
\end{tabular}

Data are in mean $\pm \mathrm{SD}$; ${ }^{*}$ indicates a significant difference at a $5 \%$ probability level.

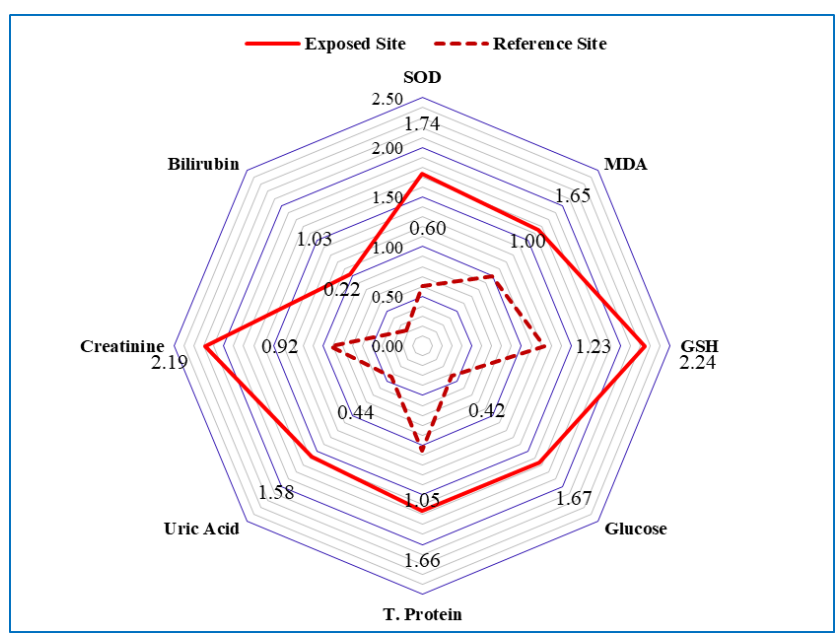

Figure (1): Star plots for IBR in Nile Tilapia from the polluted site and reference site.

\section{DISCUSSION}

Industrial pollution extremely aggregated over the last decade (da Silva and Gouveia, 2020). Egyptian water courses receive huge quantities of partially treated or untreated industrial wastewater (El-Sheekh, 2017). 


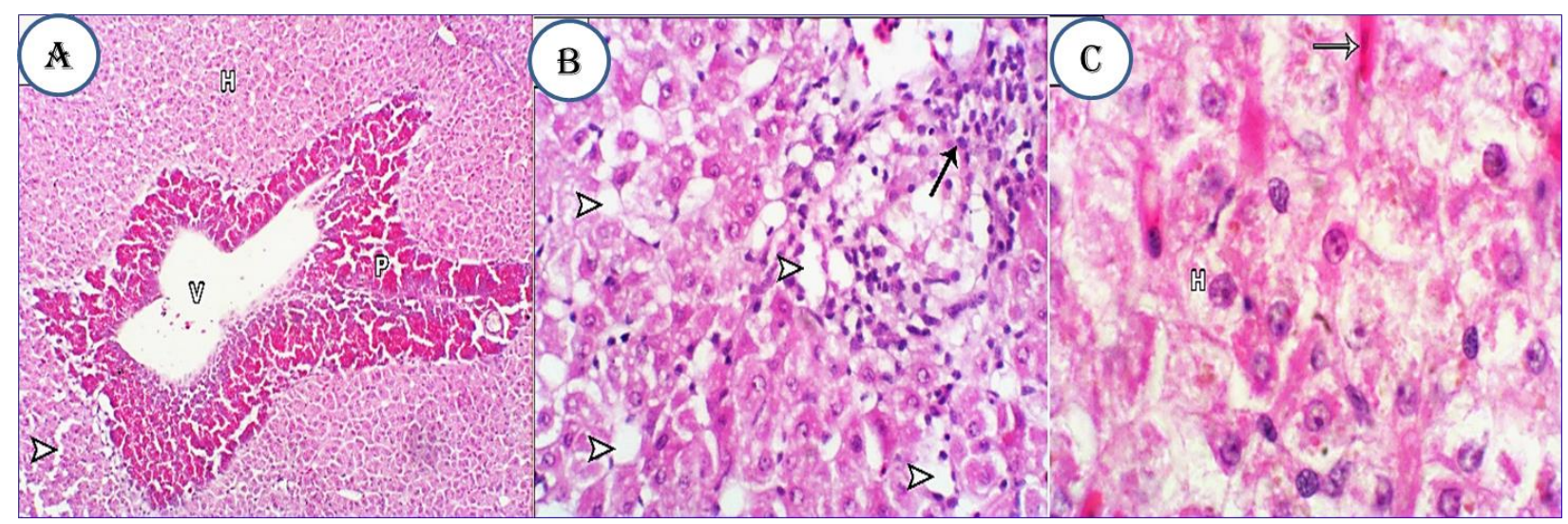

Figure (2): Photomicrograph of the liver of tilapia sampled from the Nile River showing intact central vein (V) with surrounded pancreatic tissue $(\mathrm{P})$, normal hepatocytes $(\mathrm{H}), \mathrm{RBCs}$ (arrow), and a little damage represented as degeneration (arrowhead). HE, A, X100; B, X400; C, X1000

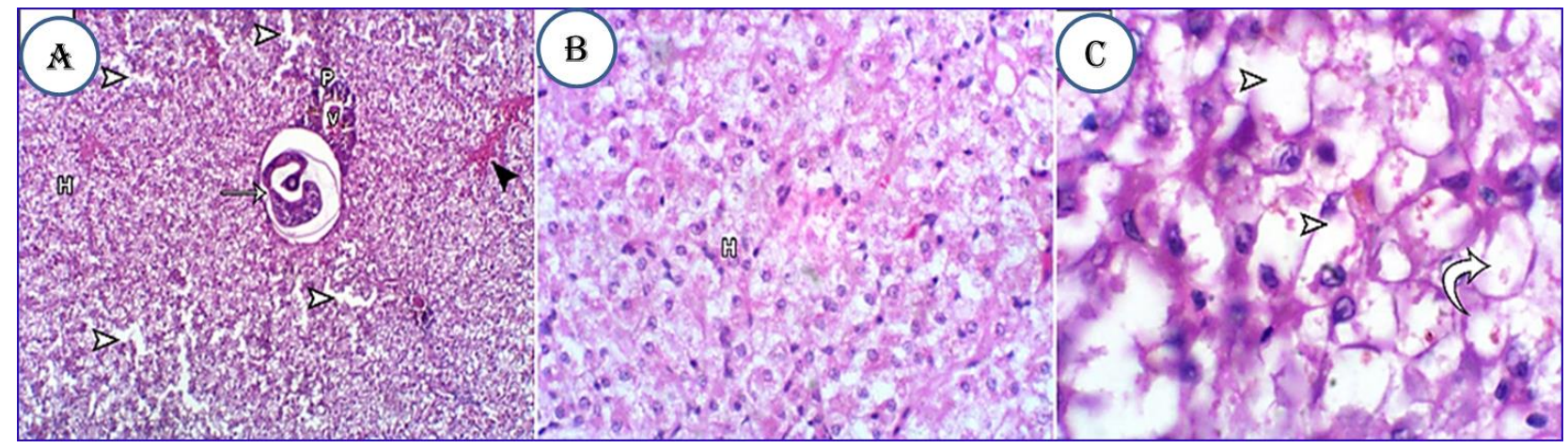

Figure (3): Photomicrograph of the liver of tilapia sampled from the drainage canal showing intact central vein (V) with surrounded pancreatic tissue $(\mathrm{P})$, encysted Parasite (white arrow), distorted hepatocytes $(\mathrm{H})$, blood sinusoid congestion (black arrowhead), degeneration (white arrowhead), lymphocytes infiltration (black arrow), and vacuolation (curved arrow). HE, A, X100; B, X400; C, X1000.
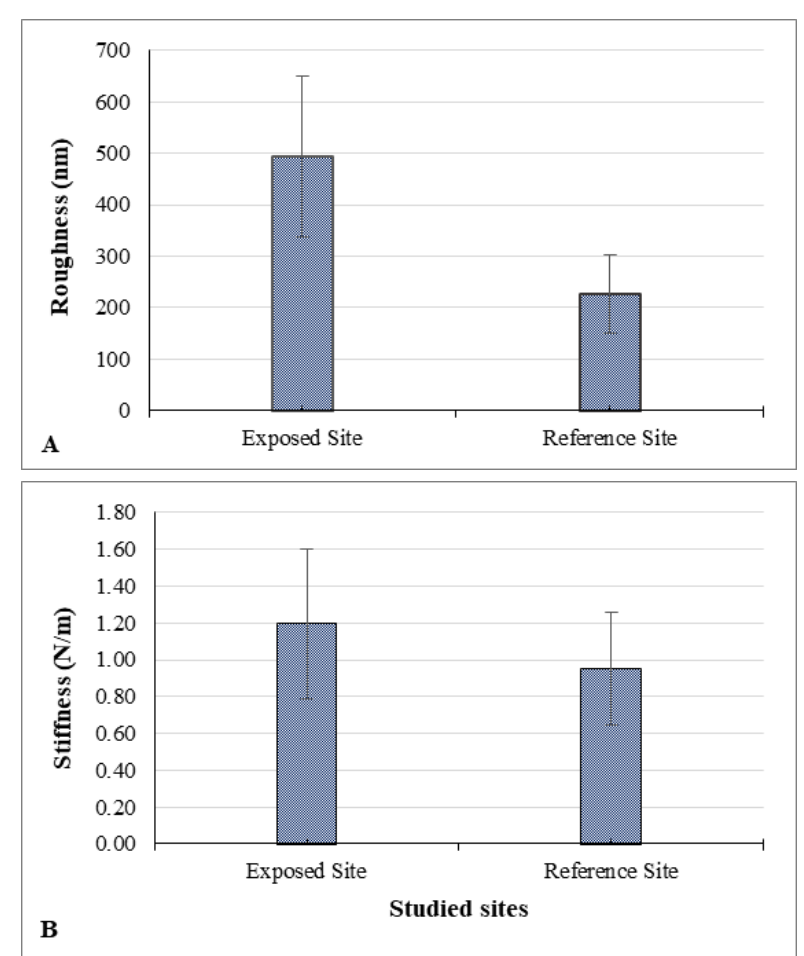

Figure (4): A, Roughness of the Liver parenchyma of the Nile tilapia; B, Stiffness of the Liver paren-chyma of the Nile tilapia.
Industrial wastewater is polluted by heavy metals, PAHs, and biodegradable organic matter (Adeogun, 2012; da Silva and Gouveia, 2020). Heavy metals pose serious consequences for the aquatic habitat and inhabitant biota. Their adverse impacts might not become apparent until severe modifications appear when it may be too late to take required countermeasures (Oyeleke et al., 2018). The current study, therefore, investigated the use of histological, nanomechanical, and biochemical parameters in the Nile tilapia O. niloticus as a signature of metal stress.

The significantly high metal concentrations in fish from the drainage canal reflect the exposure of fish to high metal stress. Several studies reported similar high metal contents in fish tissues caught from water streams adjacent to industrial factories (Abdel-Mohsien and Mahmoud, 2015; Ayeloja et al., 2014; Mendil et al., 2005). The invasion of fish by heavy metals causes a severe adverse impact on fish health. Fish develops defence mechanisms against the damaging impact of heavy metals and other pollutants. However, heavy metals at excessive levels can damage fish organs, disrupt immune response, alter hematological parameters, and weaken fish adaptation abilities and resistance to diseases (Sinha et al., 2002; Förstner and Wittmann, 2012). 
According to a pilot trial, preliminary analysis, the Damietta Branch of the Nile River is a slightly polluted stream and this finding confirms the other studies done by El-Sheekh, (2017). In this study, the mean concentrations of $\mathrm{Cd}, \mathrm{Fe}, \mathrm{Mn}, \mathrm{Co}$, and $\mathrm{Pb}$ in muscle tissue of the Nile tilapia, from the sugarbeet drainage canal, exceeded those in fish from the Nile River. Moreover, levels of $\mathrm{Cd}$ and $\mathrm{Pb}$ exceeded the maximum permissible limit $(0.5 \mathrm{ppm})$ set by World Health Organization (2003). Several studies reported similar trends of metal bioaccumulation in fish tissues from water streams adjacent to industrial factories (e.g., Authman et al., 2013; Javed et al., 2017). Authman et al., (2013) investigated the Sabal drainage canal (AlMenoufiya, Egypt) and showed that metals accumulated in organs of $O$. niloticus at high concentrations. Javed et al., (2017) measured metal levels in organs of Channa punctatus exposed to pollutants from a power plant. They reported high levels of heavy metals in all fish organs.

Cd causes biochemical, physiological, oxidative stress, and severe histopathological changes (Van der Oost et al., 2003; Otludíl et al., 2017; Kumar Maurya et al., 2019). Despite being an essential element for biological systems, excess iron could also pose severe effects on the fish body. A high level of Fe limits the motion of the fish to resources such as food and oxygen through its deposition on gills (Teien et al., 2008). Mn is essential for aquatic organisms if present below limited concentrations in their bodies. It plays a vital role in physiological metalloenzymes, bone structure, and normal functioning of the nervous system (FDA/EPA, 2001; World Health Organization, 2003). Among the effects of exposure to high $\mathrm{Mn}$ content are neurotoxicity and liver changes. When Co enters the body, it is transferred through the blood into all organs, especially the liver and bones (Javed and Usmani, 2013; Otludill et al., 2017). When $\mathrm{Pb}$ enters the fish body, it is transferred to red blood cells and attacks hemoglobin and membranes (Jaishankar et al., 2014; Mbewe et al., 2016).

SOD is considered as the first and most important line of defence against oxidative stress by catalyzing the conversion of superoxide anions in different stages of aerobic metabolism into $\mathrm{O}_{2}$ and $\mathrm{H}_{2} \mathrm{O}_{2}$. Hydrogen peroxide is subsequently converted into $\mathrm{H}_{2} \mathrm{O}$ by the action of catalase and glutathione peroxide (Javed et al., 2016). In this study, the increased SOD activity in the Nile tilapia could be attributed to metal pollution in the drainage canal on fish. The studied heavy metals are potentially redox-active that causes an imbalance between the production of free radicals in the fish (Velkova-Jordanoska et al., 2008). This oxidative stress leads to an induction of the antioxidant defence mechanisms (Javed et al., 2016). Similar findings have also been recorded in $C$. punctatus (Javed et al., 2016), O. niloticus (Nofal et al., 2019), and Abramis brama (Tenji et al., 2020).

The level of MDA, considered for lipid peroxidation, can intensively react with compounds that seriously damage enzymes and membranes in which a decrease membranous electric resistance and fluidity were reported. This stress leads to the destruction of membrane structure and physiological integrity (Üner et al., 2006; Ji et al., 2010; Javed et al., 2016). Increased MDA rates in fish sampled from the drainage canal of Kalabsho sugarbeet factory indicate the disturbance in membrane phospholipids due to pollution exposure. Several studies reported the increase of MDA concentrations in fish exposed to xenobiotics (Üner et al., 2006), pollutants (Ji et al., 2010), and heavy metals (Javed et al., 2016).

GSH is the most important non-protein thiol in cells; it has a vital role in the protection of intracellular components against toxins such as $\mathrm{Cd}$ and $\mathrm{Pb}$ through the action of GR, GST, and GPx (Mosleh et al., 2005, 2006). There was a decline in GSH levels in fish dwelling in the drainage canal in this study. Similar observations were reported in the works of Rajeshkumar et al. (2013) and Jia et al., (2019), who attributed the consumption of GSH to high degrees of pollution.

Fish in the drainage canal exhibited a hyperglycemic response, where fish generate more glucose to produce the energy utilized in combating the stress induced by environmental pollution (Nemcsok and Boross, 1982). This induction, of hepatic gluconeogenic enzymes and high substrate supply by cortisol hormones, may account for this response (Neerat-anaphan and Khammanichanha, 2015). Moreover, the detected heavy metals and other pollutants in the drainage canal might cause pancreatic cell damage, resulted in reducing insulin activity (Osman et al., 2018). Increased levels of glucose were previously recorded in the blood of fish exposed to heavy metals (Levesque $e t$ al., 2002).

Plasma proteins are pivotal to vital blood activities, such as homeostasis, vitamin transport, and immune response (Javed et al., 2016; Kim et al., 2017). Total proteins are considered an indicator of liver impairment (Kim et al., 2017). Fish in the drainage canal is exposed to toxins that might affect the liver tissue, ultimately producing an increase in plasma protein levels. This finding is supported by the work of Osman et al. (2018) and Salaah et al., (2018).

High levels of uric acid and creatinine were detected in fish collected from the drainage canal of Kalabsho sugarbeet factory. These findings may be attributed to muscle tissue damage, impaired nitrogen metabolism, and renal dysfunction which leads to a decrease in the excretion of these compounds and an increase in their levels in the blood (Osman et al., 2018; Salaah et al., 2018). RBCs breakdown may account for a high level of bilirubin (Zhou et al., 2009). These findings are in agreement with Salaah et al., (2018) study. They reported high levels of these compounds in fish serum from three polluted areas from Rosetta branch.

The IBR is a valuable approach that provides a comprehensive overview of the fish responses to pollution in one value and one-star plot. The IBR also showed a strong correlation with the heavy metal levels. This finding is in agreement with Gao et al., 
(2020) who used the (IBR) index approach to evaluate the impact of heavy metals on fish inhabiting Dianchi Lake, China. It is, therefore, could be used as an indicator of metal pollution or the overall health status of an ecosystem.

The liver plays a key role in a range of critical functions such as accumulation, biotransformation, metabolism, and excretion of toxins (Moon et al., 1985; Triebskorn et al., 2008). The liver is highly sensitive to contaminants and any change in its structure can act as an important indicator in the estimation of fish health. Histopathological changes (such as degeneration, necrosis, and vacuolation) in the liver of fish exposed to heavy metals have been reported by many authors (Abdel-Moneim et al., 2012; Akaishi et al., 2005; Mela et al., 2007; Sarkar et al., 2005). Such changes in hepatocytes occur under the influence of various PAHS and heavy metals (Jee et al., 2005; Velisek et al., 2009).

AFM is a powerful tool that has been recently employed in biology to study cell topography at the nanoscale level (Müller and Dufrêne, 2011). AFM determines the surface roughness and stiffness of tissue with qualitative and quantitative information. The morphological change provoked by apoptosis causes alterations in the change of membrane roughness (Wang et al., 2009). Therefore, the variation of membrane roughness could be an indicator for early pollution-induced cell death.

In the present study, the stiffness and roughness of the liver parenchyma were significantly higher for liver tissue of fish collected from the drainage canal. This finding supports the histopathological observations (necrosis and degeneration) discussed in this study. These findings indicate that the fish inhabiting the drainage canal is subjected to high environmental stress. Apoptotic cells tend to exhibit higher levels of membrane roughness. Similar findings were observed in rats treated by CCL4 (Khalil et al., 2020) and mouse cells treated by $\mathrm{H}_{2} \mathrm{O}_{2}$ (Wang et al., 2009). The present study could be the first study to measure stiffness and roughness in order to evaluate the impact of water pollution at the cellular level.

\section{CONCLUSIONS}

The Nile tilapia $O$. niloticus has been proved a good candidate in ecotoxicological studies due to its abundance, widespread distribution, resistance to pollution, and prompt response to chemicals. The biomarker responses of the Nile tilapia effectively demonstrate the presence of xenobiotics in the aquatic habitat. The analyzed parameters in this study shed light on the adverse impact of the sugarbeet industry on aquatic ecosystems and their biota.

\section{ACKNOWLEDGMENTS}

The authors are grateful to the Department of Zoology, Faculty of Science, Mansoura University for providing the necessary facilities.

\section{REFERENCES}

American Public HeAlth Association, 2012. Standard methods for the examination of water and wastewater. 22nd ed. APHA, Washington.

ABDEL-Mohsien, H.S. AND M.A.M. MAHMOUD. 2015. Accumulation of some heavy metals in Oreochromis niloticus from the Nile in Egypt: Potential Hazards to Fish and Consumers. Journal of Environmental Protection, 6 (9), 1003-13.

AbDEl-Moneim, A.M., M.A. Al-Kahtani, AND O.M. ELMENSHAWY. 2012. Histopathological biomarkers in gills and liver of Oreochromis niloticus from polluted wetland environments, Saudi Arabia. Chemosphere, 88 (8), 1028-35.

AdEOGUN, A.O. 2012. Impact of industrial effluent on water quality and gill pathology of Clarias gariepinus from Alaro Stream, Ibadan, Southwest, Nigeria. European Journal of Scientific Research, 76 (1), 83-94.

AKAISHI, F.M., I.S. RABITTO, J.R.M.A. CostA, H.C.S. DE Assis, A. ANJos, M.A.F. RANDI, AND C.A.O. RIBEIRO. 2005. Effects of dietary $\mathrm{Pb}$ (II) and tributyltin on neotropical fish, Hoplias malabaricus: histopathological and biochemical findings. Ecotoxicology and Environmental Safety, 60, 147-56.

Authman, M.N.N., H.H. ABbas, AND W.T. ABbas. 2013. Assessment of metal status in drainage canal water and their bioaccumulation in Oreochromis niloticus fish in relation to human health. Environmental Monitoring and Assessment, 185 (1), 891-907.

Ayeloja, A.A., F.O.A. GeOrge, A.Y. Shorinmade, W.A. JIMOH, Q.O. AFOLABI, AND K.D. OLAWEPO,. 2014. Heavy metal concentration in selected fish species from Eleyele reservoir Ibadan Oyo State South-western Nigeria. African Journal of Environmental Science and Technology, 8 (7), 422-7.

BARHAM, D. AND P. TRINDER. 1972. Enzymatic determination of uric acid. Analyst, 97, 142-5.

BELIAEFF, B. AND T. BURGEOT. 2010. Integrated biomarker response: a useful tool for ecological risk assessment. Environmental Toxicology \& Chemistry, 21 (6), 1316-22.

BERNET, D., H. SCHMIDT, W. MEIER, P. BurkHARdTHOLM, AND T. WAHLI. 1999. Histopathology in fish: Proposal for a protocol to assess aquatic pollution. Journal of Fish Diseases, 22 (1), 2534.

DhaneEsh, K. V., Gopi, M., Noushad, K. M., Ganeshamurthy, R., Kumar, T. T. A., AND BALASUBRAMANIAN, T. 2012. Determination of metal levels in thirteen fish species from Lakshadweep Sea. Bulletin of Environmental Contamination and Toxicology, 88 (1): 69-73.

DEN BESTEN, P.J. AND M. MUNAWAR, EDS. 2016. Ecotoxicological testing of marine and freshwater ecosystems: emerging techniques, 
trends and strategies. CRC Press, London.

Beutler, E., O. DuRON, AND B.M. Kelly. 1963. Improved method for the determination of blood glutathione. The Journal of Laboratory and Clinical Medicine, 61, 882-8.

El-Hais, A.M.A., M. ABD, E.-F. El-KASHEIF, AND S. ABDALLAH. 2017. Impact of heavy metals pollution on histopathological alterations in kidney and liver of nile tilapia (Oreochromis niloticus) inhabiting El-rahawy drain. Egyptian Journal of Nutrition and Feeds, 20 (2), 285-296.

EL-SHEEKH, M.M. 2017. Impact of water quality on ecosystems of the Nile River. In Handbook of Environmental Chemistry. Springer Verlag, pp. 357-85.

FDA/EPA. 2001. Fish and Fisheries Products Hazards \& Controls Guidance. Appendix 5 - FDA \& EPA Safety Levels in Regulations and Guidance. New York, FDA.

FILIPOVIĆ, V. AND B. RASPOR. 2003. Metallothionein and metal levels in cytosol of liver, kidney and brain in relation to growth parameters of Mullus surmuletus and Liza aurata from the Eastern Adriatic Sea. Water Research, 37 (13), 3253-62.

FÖRSTNER, U. AND G.T.W. WITTMANN. 2012. Metal pollution in the aquatic environment. $2^{\text {nd }}$ ed., Springer-Verlag, Berlin.

Gabr, G., Masood, M., Radwan, E., Radwan, K., Ghoenim, A. (2020). 'Potential Effects of Heavy Metals Bioacc-umulation on Oxidative stress Enzymes of Mediterranean clam Ruditapes decus-satus', Catrina: The International Journal of Environmental Sciences, 21(1), pp. 7582.doi:10.21608/cat.2020.24051.1042

GaO, Y., FAnG, L., XIANG, Q. Q., WANG, D., DinG, L. Y., DING, C. Z., \& CHEN, L. Q. 2020. Ecological risk assessment of heavy metals in fish from the Dianchi Lake, China using the integrated biomarker response approach. Environmental Science and Pollution Research, 27 (36), 4571245721.

GHARRED, T. AND A. NAIJA. 2015. Assessment of Oxidative stress and histopathological biomarkers in the parablennius incognitus fish as potential contamination indicators of the bay of sousse (Tunisia). Journal of Marine Science: Research \& Development, 05 (03), 3-9.

Henry, R., C. COMmon, AND J. Winkelman. 1974. Clinical chemistry: Principles and Techniques. 2nd ed., Harper \& Row, New York.

HENRY, R.J. 1964. Colorimetric determination of total protein. In Clinical Chemistry. Harper and Row, New York, pp. 181

JAIN, S.K., R. MCVIE, J. DuetT, AND J.J. HeRbST. 1989. Erythrocyte membrane lipid peroxidation and glycosylated hemoglobin in diabetes. Diabetes, 38 (12), 1539-43.

JAISHANKAR, M., T. TSETEN, N. ANBALAGAN, B.B. MATHEW, AND K.N. BEEREGOWDA. 2014. Toxicity, mechanism and health effects of some heavy metals. Interdisciplinary Toxicology.

JAVED, M., I. AHMAD, N. USMANI, AND M. AHMAD.
2016. Bioaccumulation, oxidative stress and genotoxicity in fish (Channa punctatus) exposed to a thermal power plant effluent. Ecotoxicology and Environmental Safety, 127, 163-9.

JAVED, M. AND N. UsMANI. 2013. Assessment of heavy metal $(\mathrm{Cu}, \mathrm{Ni}, \mathrm{Fe}, \mathrm{Co}, \mathrm{Mn}, \mathrm{Cr}, \mathrm{Zn})$ pollution in effluent dominated rivulet water and their effect on glycogen metabolism and histology of Mastacembelus armatus. SpringerPlus, 2 (1), 390.

JEE, J.H., F. MASROOR, AND J.C. KANG. 2005. Responses of cypermethrin-induced stress in haematological parameters of Korean rockfish, Sebastes schlegeli (Hilgendorf). Aquaculture Research, 36 (9), 898-905.

JI, Y., G. LU, C. WANG, W. SonG, AND H. Wu. 2010. Fish transplantation and stress-related biomarkers as useful tools for assessing water quality. Journal of Environmental Sciences, 22 (11), 1826-32.

JIA, R., Y. LI, L. CAO, J. DU, T. ZHENG, H. QIAN, Z. GU, G. JENEY, P. XU, AND G. YIN. 2019. Antioxidative, anti-inflammatory and hepatoprotective effects of resveratrol on oxidative stress-induced liver damage in tilapia (Oreochromis niloticus). Comparative Biochemistry and Physiology Part - C: Toxicology and Pharmacology, 215 (10), 56-66.

KHALIL, M.R., R.S. EL-DEMERDASH, H.H. Elminshawy, E.T. Mehanna, N.M. Mesbah, AND D.M. ABO-ElmAtTy. 2020. Therapeutic effect of bone marrow mesenchymal stem cells in a rat model of carbon tetrachloride induced liver fibrosis. Biomedical Journal, (May), 1-13.

KHALIL, M.T., N.S. GAD, N.A.M. AHMED, AND S.S. MoustafA. 2017. Antioxidant defense system alternations in fish as a bio-indicator of environmental pollution. Egyptian Journal of Aquatic Biology and Fisheries, 21 (3), 11-28.

KIM, J.H., C.W. OH, AND J.C. KANG. 2017. Antioxidant responses, neurotoxicity, and metallothionein gene expression in Juvenile Korean rockfish sebastes schlegelii under dietary lead exposure. Journal of Aquatic Animal Health, 29 (2), 112-9.

Kumar Maurya, P., D.S. MALIK, K. Kumar YADAV, N. GUPTA, AND S. KUMAR. 2019. Haematological and histological changes in fish Heteropneustes fossilis exposed to pesticides from industrial waste water. Human and Ecological Risk Assessment, 25 (5), 1251-78.

Levesque, H.M., T.W. MoON, P.G.C. CAMPBElL, AND A. Hontela. 2002. Seasonal variation in carbohydrate and lipid metabolism of yellow perch (Perca flavescens) chronically exposed to metals in the field. Aquatic Toxicology, 60 (3-4), 257-67.

LOTT, J.A. AND B.T. DoumAS. 1993. 'Direct' and total bilirubin tests: Contemporary problems. Clinical Chemistry, 39 (4), 641-7.

Mbewe, G., M. Mutondo, K. MaseKa, And K. SiCHILONGO. 2016. Assessment of Heavy-Metal Pollution in Sediments and Tilapia Fish Species in Kafue River of Zambia. Archives of 
Environmental Contamination and Toxicology, 71 (3), 383-93.

MCCORD, J.M. AND I. FRIDOVICH. 1969. Superoxide dismutase. An enzymic function for erythrocuprein (hemocuprein). Journal of Biological Chemistry, 244 (22), 6049-55.

MEdEIROS, R.J., L.M.G. DOS SANTOS, A.S. FreIRE, R.E. SANTELli, A.M.C.B. Braga, T.M. KrausS, AND S. DO C. JACOB. 2012. Determination of inorganic trace elements in edible marine fish from Rio de Janeiro State, Brazil. Food Control, 23 (2), 535-41.

Mela, M., M.A.F. RANDI, D.F. Ventura, C.E.V. Carvalho, E. Pelletier, AND C.A. Oliveira RIBEIRO. 2007. Effects of dietary methylmercury on liver and kidney histology in the neotropical fish Hoplias malabaricus. Ecotoxicology and Environmental Safety, 68 (3), 426-35.

MENDIL, D., Ö. DoĞAN UluÖZlü, E. HASDEMIR, M. TÜZEN, H. SARI, AND M. SUIÇMEZ. 2005. Determination of trace metal levels in seven fish species in lakes in Tokat, Turkey. Food Chemistry, 90 (1-2), 175-9.

Monteiro, D.A., F.T. RANTIN, AND A.L. KALININ. 2010. Inorganic mercury exposure: Toxicological effects, oxidative stress biomarkers and bioaccumulation in the tropical freshwater fish matrinxã, Brycon amazonicus (Spix and Agassiz, 1829). Ecotoxicology, 19 (1), 105-23.

MoON, T.W., P.J. WALsh, AND T.P. MOMMSEN. 1985. Fish hepatocytes: a model metabolic system. Canadian Journal of Fisheries and Aquatic Sciences, 42 (11), 1772-82.

Mosleh, Y.Y., S. PARIS-PALACIOS, AND S. BiAgIANTIRISBOURG. 2006. Metallothioneins induction and antioxidative response in aquatic worms Tubifex tubifex (Oligochaeta, Tubificidae) exposed to copper. Chemosphere, 64 (1), 121-8.

Mosleh, Y.Y., S. Paris-Palacios, M. Couderchet, S. Biagianti-RisbourG, AND G. VERnET. 2005. Metallothionein induction, antioxidative responses, glycogen and growth changes in Tubifex tubifex (Oligochaete) exposed to the fungicide, fenhexamid. Environmental Pollution, 135 (1), 73-82.

MÜlLER, D.J. AND Y.F. DUfRÊNE. 2011. Atomic force microscopy: A window on the cell surface. Trends in Cell Biology, 21 (8), 461-9.

Museum, H. 2015. Detection of Some Heavy Metals in Muscle and Gills of the Nile Tilapia (Oreochromis niloticus L.) Raised in the Treated Sewage Wastewater. Master's thesis, University of Khartoum.

NEERATANAPHAN, A. AND L. KhammanichanHA. 2015. Water Quality and Heavy Metals Contamination in Water, Sediment and Nile Tilapia (Oreochromis niloticus) from Domestic Wastewater Canal. The Society of Higher Education Institutes on Environment, (9), 251-7.

NeMCSOK, J. AND L. Boross. 1982. Comparative studies on the sensitivity of different fish species to metal pollution. Acta Biologica Academiae
Scientiarum Hungaricae, 33 (1), 23-7.

NofAL, M.I., V.H. ZAKI, AND N.A.S. AHMED. 2019. Effects of heavy metal pollution on Nile tilapia in Manzala farm: Oxidative stress biomarkers and histopathological findings. International Journal of Fisheries and Aquatic Studies, 7 (5), 315-28.

Osman, A.G.M., K.Y. ABOUElFadL, A.E.B.M. ABD El ReHEEM, U.M. MAHMOUD, W. KlOAS, AND M.A. MoustafA. 2018. Blood Biomarkers in Nile tilapia Oreochromis niloticus and African Catfish Clarias gariepinus to Evaluate Water Quality of the River Nile. Journal of FisheriesSciences.com, 12 (1), 1-15.

OTLudİL, B., H. KARADEDE AKIN, AND E. ÜNLÜ. 2017. Effects of sub-lethal exposure of cadmium on histopathology of gills of Nile tilapia, Oreochromis niloticus and the mitigating effects of Cladophora glomerata. Türk Biyoloji Dergisi, 30 (1), 24-30.

OYELEKE, P.O., F.J. OKPARAOCHA, AND O.A. ABIODUN. 2018. Human health risk assessment of heavy metals (lead, cadmium and copper) in fresh water tilapia fish (Oreochromis niloticus) from Eleyele River, Ibadan, Southwestern Nigeria. Chemistry Research Journal, 3 (4), 13442.

QADRI, H. AND R.A. BHAT. 2020. The concerns for global sustainability of freshwater ecosystems. In Fresh Water Pollution Dynamics and Remediation, Springer, Singapore, pp. 1-13.

RAJEShKumar, S., J. Mini, AND N. Munuswamy. 2013. Effects of heavy metals on antioxidants and expression of HSP70 in different tissues of Milk fish (Chanos chanos) of Kaattuppalli Island, Chennai, India. Ecotoxicology and Environmental Safety, 98, 8-18.

SALAAH, S.M., M.T. KHALIL, N.S. GAD, AND N.A.M. AHMED. 2018. Physico-chemical characteristics and physiological changes in Oreochromis niloticus from rosetta branch of the river Nile. European Chemical Bulletin, 7 (2), 63-71.

SARKar, B., A. ChatterJee, S. AdhiKari, AND S. AYYAPPAN. 2005. Carbofuran- and cypermethrin-induced histopathological alterations in the liver of Labeo rohita (Hamilton) and its recovery. Journal of Applied Ichthyology, 21 (2), 131-5.

DA Silva, F.J.G. AND R.M. Gouveia. 2020. Global population growth and industrial impact on the environment. In Cleaner Production. Springer, London, pp. 33-75.

Sinha, A.K., P. DAsgupta, S. Chakrabarty, G. BHATTACHARYYA, AND S. BHATTACHARJEE. 2002. Bio-accumulation of heavy metals in different organs of some of the common edible fishes of Kharkai River, Jamshedpur. Indian Journal of Environmental Health, 44 (2), 102-7.

SOUNDARARAJAN, M. AND G. VEERAIYAN. 2014. Effect of heavy metal Arsenic on haematological parameters of freshwater fish, Tilapia mossambica. International Journal of Modern Research and Reviews, 2 (3), 132-135. 
TEIEN, H.C., Ø.A. Garmo, ̊̊. ÅtLAnd, And B. SAlbU. 2008. Transformation of iron species in mixing zones and accumulation on fish gills. Environmental Science and Technology, 42 (5), 1780-6.

Tenji, D., B. Micic, S. Sipos, B. MiljanoviC, I. TeOdorovic, AND S. KAISAREVIC. 2020. Fish biomarkers from a different perspective: evidence of adaptive strategy of Abramis brama (L.) to chemical stress. Environmental Sciences Europe, 32 (1), 1-15.

Triebskorn, R., I. TElCEAN, H. CASPER, A. FARKAS, C. SANDU, G. Stan, O. ColÂrescu, T. Dori, AND H.R. KÖHLER. 2008. Monitoring pollution in River Mureş, Romania, part II: Metal accumulation and histopathology in fish. Environmental Monitoring and Assessment, 141 (1-3), 177-88.

TRINDER, P. 1969. Determination of glucose concentration in the blood. Annals of Clinical Biochemistry, 6, 24-27.

ÜNER, N., E.Ö. ORUÇ, Y. SEVGILER, N. ŞAHIN, H. DURMAZ, AND D. USTA. 2006. Effects of diazinon on acetylcholinesterase activity and lipid peroxidation in the brain of Oreochromis niloticus. Environmental Toxicology and Pharmacology, 21 (3), 241-5.

VAN DER OOST, R., J. BEYER, AND N.P.E. VERMEULEN. 2003. Fish bioaccumulation and biomarkers in environmental risk assessment: A review. Environmental Toxicology and Pharmacology,
13 (2), 57-149.

VeliseK, J., Z. Svobodova, AND V. Piackova. 2009. Effects of acute exposure to bifenthrin on some haematological, biochemical and histopathological parameters of rainbow trout (Oncorhynchus mykiss). Veterinarni Medicina, 54 (3), 131-7.

VELKOVA-JORDANOSKA, L., G. KOSTOSKI, AND B. JORDANOSKA. 2008. Antioxidative enzymes in fish as biochemical indicators of aquatic pollution. Bulgarian Journal of Agricultural Science, 14 (2), 235-7.

WAng, J., Z. WAN, W. LiU, L. Li, L. Ren, X. WANG, P. Sun, L. REN, H. ZHAO, Q. TU, Z. ZHANG, N. SONG, AND L. ZHANG. 2009. Atomic force microscope study of tumor cell membranes following treatment with anti-cancer drugs. Biosensors and Bioelectronics, 25 (4), 721-7.

World HeAlth ORGanization. 2003. Guideline for drinking water quality health criteria and other supporting information edition of guidelines on drinking water quality. 2nd ed. WHO, Geneva, Switzerland.

YAP, C.K., A. JusOH, W.J. LeONG, A. KARAMI, AND G.H. ONG. 2015. Potential human health risk assessment of heavy metals via the consumption of tilapia Oreochromis mossambicus collected from contaminated and uncontaminated ponds. Environmental Monitoring and Assessment, 187 (9), 584.

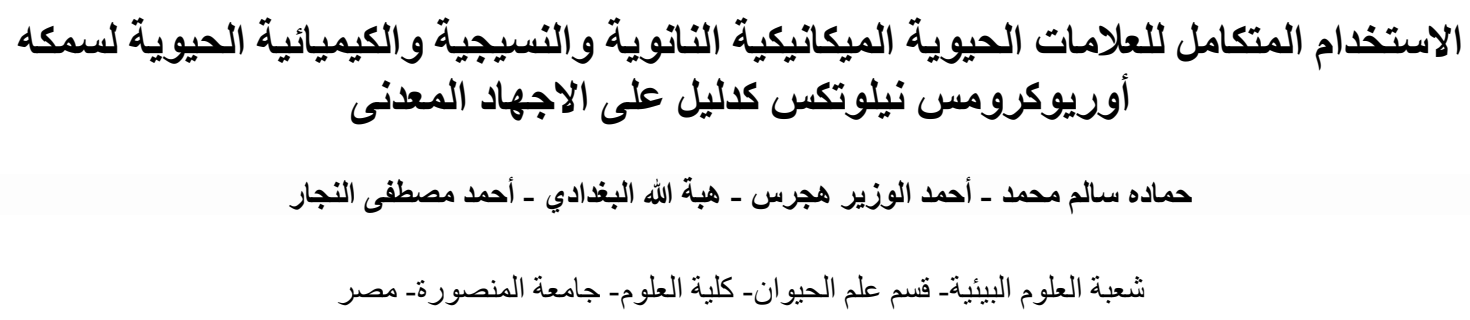

الملخص العربـي

يعتبر تلوث الماء بالمعادن الثقيلة يعرض الأسماك الموجودة للتلوث بهذه المعادن وهي مشكلة بيئية تشكل خطر علي صحة الانسان.، حيث

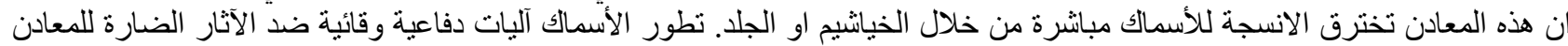

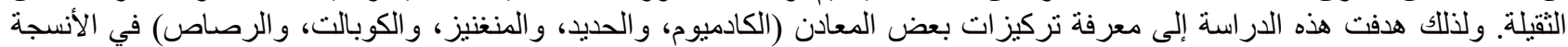

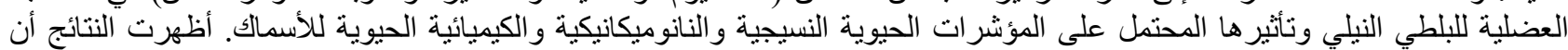

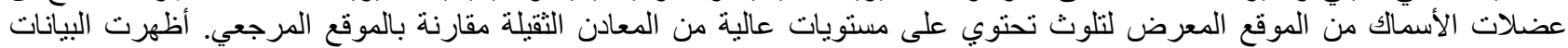

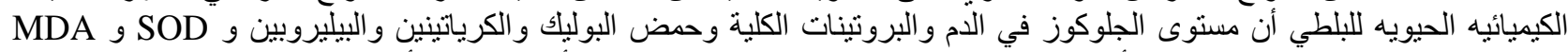

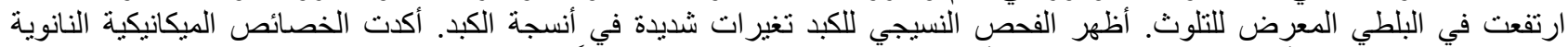

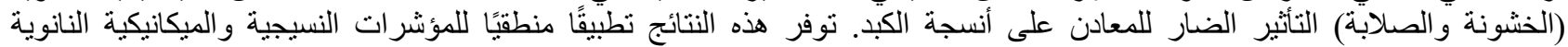

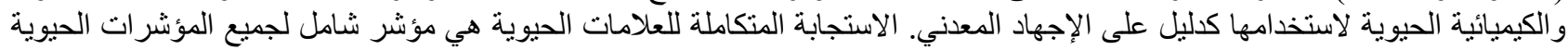
ومؤشر جيد للحالة الصحية للنظام البيئي المائي. 